\title{
進行波音波を用いた共鳴管冷凍機*
}

\author{
上田 祐 樹*1, 加 藤千幸*1
}

\section{Traveling-Wave Thermoacoustic Refrigerator}

\author{
Yuki UEDA*2 and Chisachi KATO \\ ${ }^{* 2}$ Institute of Industrial Science, The University of Tokyo, \\ 4-6-1 Komaba, Meguro-ku, Tokyo, 153-8505 Japan
}

\begin{abstract}
A new type of speaker-driven thermoacoustic refrigerator is described. By the measurement of the acoustic field formed in the refrigerator, it is shown that the refrigerator uses a traveling-acoustic wave for heat pumping through ideally reversible heat transfer. It is also shown that the efficiency of the refrigerator is improved by the suppression of mass flow through a regenerator. The new refrigerator has a potential to realize a high efficiency compared with previous speaker-driven thermoacoustic refrigerators using standing-acoustic wave because previous ones use intrinsically irreversible heat transfer.
\end{abstract}

Key Words: Energy Conversion, Heat Pump, Refrigeration, Thermoacoustics

\section{1. 緒}

音波が管内を伝ぱすると，管の軸方向にヒートポン プ効果が現れる。この音波によるヒートポンプ効果は Merkli-Thomann によって 1975 年に初めて観測され た(1).その後，この効果を応用した共鳴管冷凍機が開 発された(2). 共鳴管冷凍機は音波による圧縮・膨張を 利用してヒートポンプ効果を実現するため, スピーカ などの音響入力源以外の可動部を必要としない. ま た，この冷凍機では空気やへリウムなど環境に負荷を 与えない気体が作動流体として用いられている。その ため, 共鳴管冷凍機は簡単構造で低環境負荷という利 点をもっている. 現在, 最も高い共鳴管冷凍機の成積 係数 COP はカルノーヒートポンプの成績係数 $\mathrm{COP}_{\text {Carnot }}$ の $20 \%$ 程度 ${ }^{(3)}$ である。

これまでに開発されてきた共鳴管冷凍機の概略図を 図 1 に示す. 共鳴管冷凍機はスピーカ, 共鳴管, 蓄熱 器で構成されている. 共鳴管の一端はスピーカで閉じ られ，もう一端は開端もしくは閉端になっている。ス

* 原稿受付 2006 年 3 月 15 日

*1 正員, 東京大学生産技術研究所( 153 -8505 東京都目黒区 駒場 4-6-1).

E-mail : uedayuki@iis.u-tokyo.ac.jp
ピーカを用いて共鳴管内の気柱を共鳴周波数で加振す ると, 定在波音波が共鳴管内に励起する。この定在波 音波による流体の圧力変動と流速変動によって, ヒー トポンプ効果が蓄熱器(regenerator)において生じる.

2 章で詳しく述べるが, 圧力と流速が同位相で変動 する進行波音波と $\pi / 2$ ずれて変動する定在波音波は それぞれ異なるメカニズムでヒートポンプ効果を実現 する(4). 進行波音波は本質的に流体要素と管壁の可逆 的な熱交換を利用し，定在波音波は不可逆的な熱交換 を利用する．可逆的な熱交換を利用する進行波音波に よるヒートポンピングを用いたほうが, 定在波音波に よるヒートポンピングを用いた場合に比べて, 高い COP が実現される可能性がある(5). しかし，上述のよ うに従来の共鳴管冷凍機では定在波音波によるヒート ポンピングが用いられている.

本論文では，進行波音波を用いてヒートポンプ効果 を得る新しい夕イプの共鳴管冷凍機について述べる. 図 1 に示した共鳴管冷凍機の共鳴管内には, その形状 が原因となって定在波音波が励起する。これに対し て, 1998 年以降の熱音響エンジンの研究(6) (8) と熱駆 動熱音響冷凍機の研究(9) (12)により，ループ状の管内 には，進行波音波の励起が可能であることが明らかに なってきた。そこで, 著者らはループ状の管を共鳴管 


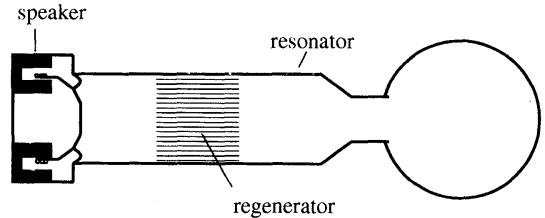

Fig. 1 Standing-wave thermoacoustic refrigerator

として用いた共鳴管冷凍機を製作した。装置内に励起 させた音波による圧力変動を測定することで, 製作し た冷凍機内で進行波音波によるヒートポンピングが行 われていることを確認した。また，この冷凍機の COP の改善策を施し, その効果を実証した.

\section{2. 音波によるヒートポンプ効果}

音波によるヒートポンプ効果を考えるうえで, 二つ のパラメータが重要になる(4)(6).一つは圧力変動と流

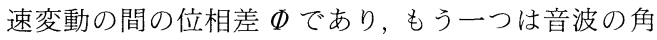
振動数 $\omega$ と熱緩和時間 $\tau$ の積 $\omega \tau$ である. $\tau$ は流体要 素とそれを囲む固体壁が熱平衡に達するまでの緩和時 間を示し, 流路半径 $r$ と流体要素の熱伝導度 $x$, 平均 密度 $\rho_{m}$, 定圧比熱 $c_{p}$ を用いて $\tau=\left(r^{2} c_{p} \rho_{m}\right) /(2 \varkappa)$ と 書ける。

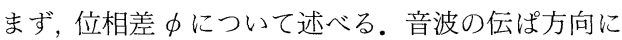
$x$ 軸をとったとき, 音波による流体要素の圧力変動 $P$ は時間 $t$ と位置 $x$ の関数として

$$
P(x, t)=p(x) \cos \omega t
$$

と書け, 流速変動 $U(x, t)$ は位相差 $\Phi(x)$ を用いて

$$
\begin{aligned}
& U(x, t)=u(x) \cos \{\omega t+\Phi(x)\} \\
& \quad=u(x) \cos \Phi(x) \cos \omega t \quad \cdots \cdots \cdots . \\
& \quad+u(x) \sin \Phi(x) \cos (\omega t+\pi / 2)
\end{aligned}
$$

と書ける.ここで, $p(x)>0, u(x)>0$ と約束し, $-\pi$ $\leq \Phi \leq \pi$ とする．自由空間を伝ぱする進行波音波での

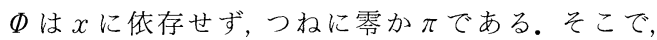
$u \cos \Phi$ を流速の進行波成分と呼ぶことにする(6). 一 方，散逸を伴わない定在波音波では圧力の節や腹を除 いた位置で $\Phi$ はつねに一 $\pi / 2$ か $\pi / 2$ になる。 そこで, $u \sin \Phi$ を流速の定在波成分と呼ぶことにする．流速

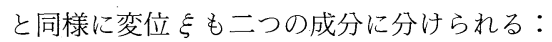

$$
\begin{gathered}
\xi(x, t)=\xi_{0}(x)+\frac{u(x)}{\omega} \cos \{\omega t+\Phi(x)-\pi / 2\} \\
=\xi_{0}(x)+\frac{u(x)}{\omega} \cos \Phi(x) \cos (\omega t-\pi / 2) \\
\quad+\frac{u(x)}{\omega} \sin \Phi(x) \cos \omega t . \quad \ldots \ldots \ldots \ldots \cdots \cdots
\end{gathered}
$$

ここで $\xi_{0}$ は流体要素の平均位置を表す。 $u / \omega \cos \Phi$

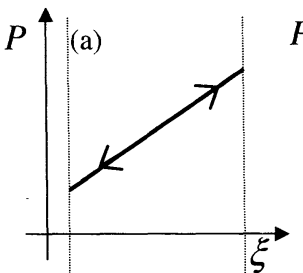

(b) $\omega \tau \ll 1$

heat release

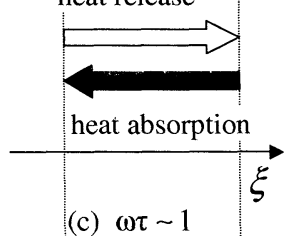

(c) $\omega \tau \sim 1$

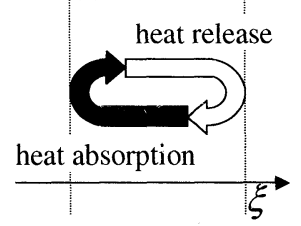

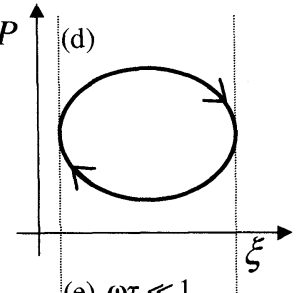

heat release
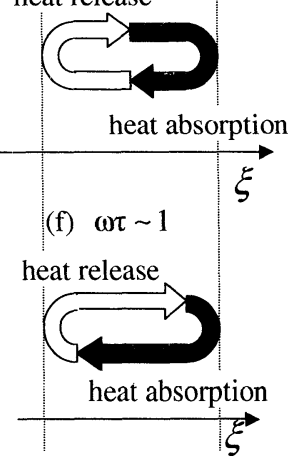

(e) $\omega \tau \ll 1$

Fig. 2 Schematic illustration of the mechanism of heat pumping executed by the standing wave component (a) $-(\mathrm{c})$ and traveling wave component (d) $-($ f )

を変位の進行波成分, $u / \omega \sin \Phi$ を定在波成分と呼ぶ ことにする．管内を伝ぱする音波は一般に純粋な進行 波でも，純粋な定在波でもない。そのため，位相差 $\Phi$ は管内の軸方向の位置 $x$ に依存し, 進行波成分と定在 波成分の割合は $x$ に依存する(6)(10)(11)(13). そこで「定 在波音波」と「進行波音波」の表現の代わりに，位相 差 $\Phi$ にってその割合が決定される「定在波成分」 と「進行波成分」を用いて議論を進める.

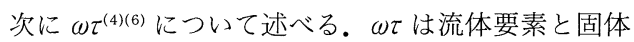
壁の間で行われる熱交換を特徵づけるパラメータであ る. $\omega \tau$ が 1 より十分小さいとき, 流体要素の温度は 固体壁の温度とつねに等しい. そのため, 流体要素と 固体壁の間の熱交換は等温可逆的に行われ, 流体要素 の圧力変動とエントロピー変動の位相は $\pi$ だけずれ る. $\omega \tau$ が 1 より十分大きいとき，流体要素は固体壁 と熱交換せず，エントロピーは変動しない. $\omega \tau$ が 1 程度のとき, 流体要素の圧力が変動すると, 流体要素 の温度と固体壁の温度に差ができる。この温度差によ る熱伝導に起因して流体要素と固体壁は不可逆的に熱 交換する。このとき，流体要素の圧力変動とエントロ ピー変動の位相差は $\pi$ から 1 程度遅れる ${ }^{(14)}$.

$2 \cdot 1$ 定在波成分による熱輸送 $\quad 0<\Phi<\pi$ のと き, 変位の定在波成分と圧力 $P$ の関係は図 $2(\mathrm{a})$ のよ 
うになる。この状態で $\omega \tau$ が 1 より十分小さい場合を 考える，この場合，上でも述べたように流体要素の温 度と固体壁の温度はつねに等しい. そのため, 図 2(b)に模式的に示したように, 右に移動しながら圧 縮されるときに流体要素は固体壁へ放熱する。その 後, 左に変位しながら膨張するときに, 放熱したのと 同量の熱量を吸熱する。放熱する場所と吸熱する場所 が同じなので, 時間平均すると流体の振動による熱 流**1 は生じず, ヒートポンプ効果は得られない(14).

$\omega \tau \sim 1$ の場合を考える. エントロピー変動と圧力変 動の間の位相差により, $\omega \tau \sim 1$ では圧力が上昇し始め るタイミングから $1 /(2 \pi)$ 周期程度遅れてから, 流体 要素は固体壁に放熱し始める。また, 圧力の下降時も, 下降した瞬間から $1 /(2 \pi)$ 周期程度遅れてから, 流体 要素は固体壁から吸熱し始める.この遅れの結果, 図 2( c ) に模式的に示したように吸熱・放熱のタイミン グと変位のタイミングがずれて, 左から右へ向かう熱 流が生じる。

定在波成分によって生じる熱流の向きは $\Phi$ の值に 依存する. $u>0, p>0$ としたので, $P-\xi$ の傾きは $\sin \Phi$ の符号によって決まる。 $-\pi<\Phi<0$ のきは $P-\xi$ の描く軌跡は負の傾きをもつ. これは, 図 2(a)に示したのとは逆に, 流体要素は左に変位しな がら圧縮され, 右に変位しながら膨張することを意味 している. したがって, $-\pi<\Phi<0$ かつ $\omega \tau \sim 1$ のと き, 熱流の向きは図 2(a)中を右から左に向かう. 定 在波成分による熱流の向きをまとめると以下のように なる. $-\pi<\Phi<0$ のき, 熱流は $\xi$ の負の方向に向 かい, $0<\Phi<\pi$ のき, 熱流は $\xi$ 正の方向に向か う.

$2 \cdot 2$ 進行波成分による熱輸送 $\quad-\pi / 2<\Phi<\pi / 2$ のとき, 変位の進行波成分と圧力 $P$ の関係を図 $2(\mathrm{~d})$ に示す. $\omega \tau \ll 10$ 状況下で進行波成分によって実行さ れるヒートポンプ効果について考える。これまでにも 述べたように, $\omega \tau \ll 1$ が満たされると, 流体要素は壁 と等温可逆的に熱交換する。 そのため, $P-\xi$ が描くだ 円の左半分の過程で, 図 $2(\mathrm{e})$ に模式的に示したよう に流体要素は固体壁に放熱する. そして, 右半分の過 程で固体壁から吸熱する. 放熱する位置と吸熱する位 置が異なるので, 1 サイクルで図 $2(\mathrm{~d})$ の右から左へ の熱流が生じる(14).

**1 断面積 $A(x)$ の断面を通過する熱流 $Q(x)$ は $Q(x)=$ $A(x) T_{m}(x) \rho_{m}(x) f \int_{0}^{T} s(x, t) U(x, t) d t$ と定義される ${ }^{(3)(4)}$ こ こで, $T_{m}(x), \rho_{m}(x), s(x, t), U(x, t)$ はそれぞれ流体要素 の平均温度, 平均密度, エントロピー変動, 流速変動であり, $T$ は周期で, $f$ は周波数である $\omega \tau \sim 1$ でも進行波成分によるヒートポンプ効果は生 じる. $\omega \tau \sim 1$ のとき, 上記したように, 圧力変動とエ ントロピー変動に位相遅れが生じる.その結果, 図 $2(\mathrm{f})$ に模式的に示すように, 放熱と吸熱の夕イミン グが図 2(e)に比べて遅れる。しかし，右から左へ向 かう熱流は生じる. 図 2(e ) と図 2(f)を比べるとわ かるように, 圧力振幅と変位振幅の大きさがそれぞれ 同じであれば, $\omega \tau \ll 1$ の場合に比べると $\omega \tau \sim 1$ のとき のほうが 1 サイクルあたりに輸送される熱量が少なく なる.

$P-\xi$ 平面に進行波成分が描くだ円は $-\pi / 2<\Phi<$ $\pi / 2$ で時計回りに回り $\pi / 2<\Phi<\pi$ および $-\pi / 2<\Phi$ $<-\pi$ で反時計回りに回る. そのため, 進行波成分に よる熱流の方向も $\Phi$ に依存する。つまり, $-\pi / 2<\Phi$ $<\pi / 2$ のとき，図 $2(\mathrm{e}),(\mathrm{f})$ で示したように右か ら左へ向かう熱流が生じ, $\pi / 2<\Phi<\pi$ および $-\pi<\Phi$ $<-\pi / 2$ のきは左から右へ向かう熱流が生じる.

熱交換の仕方の違いから， $\omega \tau \sim 1$ で生じるヒートポ ンプ効果を利用する冷凍機の COP に比べて, $\omega \tau \ll 1$ で生じるヒートポンプ効果を利用する冷凍機の COP のほうが高くなる可能性がある。 $\omega \tau \ll 1$ の環境下で実 行されるヒートポンプ効果を実現するためには, 蓄熱 器内での流路径を小さくし, かつ, 蓄熱器において位 相差 $\Phi$ を零に近づければよい.

\section{3. 実 験 装 置}

本研究では, 蓄熱器内における位相差 $\Phi$ を零に近 づけるために，進行波音波の励起を可能にするループ 管を用いて共鳴管を製作した。また， $\omega \tau \ll 1$ を実現す るためにステンレス製のメッシュを用いて蓄熱器を製 作した。

製作した共鳴管冷凍機の概略図を図 3 に示す。共鳴 管冷凍機はスピーカ, テーパ管, 枝管, ループ管で構 成されている。スピーカ(Morel Acoustics USA, MW-142) は音響用のパワーアンプ(YAMAHA, P 2500 S) を経由して, 発振機(NF, WF 19431)につな がれている。この発振機から角振動数 $\omega$ の正弦波を

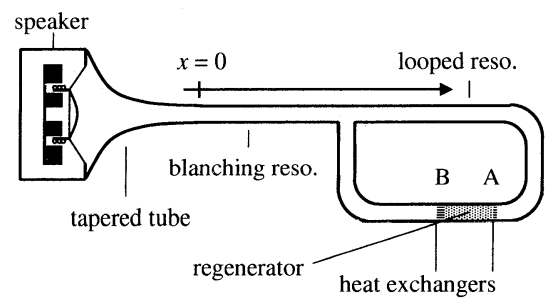

Fig. 3 Experimental setup 
出力し, スピーカを振動させる.

テーパ管の長さは $0.15 \mathrm{~m}$ であり,その内径は 160 $\mathrm{mm}$ から $24 \mathrm{~mm}$ まで指数関数的に小さくなってい る.枝管の内径は $24 \mathrm{~mm}$, 長さは $0.18 \mathrm{~m}$ である. 枝 管とループ管は T字形の管で結ばれている、ループ 管の内径は $24 \mathrm{~mm}$ で平均周長は $0.83 \mathrm{~m}$ である. 装 置内には作動流体として大気圧空気が内封されてい る.

ステンレス製のメッシュを長さ $50 \mathrm{~mm}$ に積層させ て製作した蓄熱器がループ管内に挿入されている。蓄 熱器の外径は $24 \mathrm{~mm}$ であり, 水力半径 $r$ は $0.1 \mathrm{~mm}$ である. 水力半径を用いて, 蓄熱器内での熱緩和時間 $\tau$ を算出すると $2 \times 10^{-4} \mathrm{~s}$ となる. 蓄熱器両端には長 さが $10 \mathrm{~mm}$ の熱交換器 $\mathrm{A}$ と長さが $5 \mathrm{~mm}$ の熱交換器 $\mathrm{B}$ の設置されている. 両方の熱交換器はともに幅 1 $\mathrm{mm}$ の穴が間隔 $0.5 \mathrm{~mm}$ でスリット状にあいた構造 をしている。蓄熱器の中心は $x=0.70 \mathrm{~m}$ にある。こ こで, $x$ 軸の原点は, 図 3 に示したように,テーパ管 と枝管の接合点にとり，正の方向は枝管内では左から 右へ向いており，ループ管内では時計回りに向かって いる、枝管の長さが $0.18 \mathrm{~m}$ なので, $x=0.18 \mathrm{~m}$ に枝 管とループ管の接合点がある.また，ループ管の周長 が $0.83 \mathrm{~m}$ なので, $x=0.18 \mathrm{~m}$ と $x=1.01 \mathrm{~m}$ は同じ位 置を指す.

枝管およびループ管の壁に細管(内径 $2 \mathrm{~mm}$, 長さ $10 \mathrm{~mm}$ )をつけた。この細管に小形圧力センサ (Toyodakoki, DD 102, 共鳴周波数 $5 \mathrm{kHz}$ )を取付け た(16).この圧力センサから出力された信号をフーリ

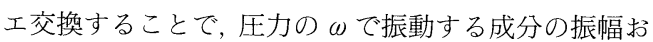
よび位相を得た。一端は閉じられ，もう一端はスピー カにつながれた共鳴管を用いた実験から，異なる位置 で測定された圧力変動間の位相差の測定誤差は $\pm 0.1^{\circ}$ と見積もられた。

発振機から出力する正弦波の周波数 $f=\omega /(2 \pi)$ を 変えながら, 装置内の圧力振幅を測定した。その結果, $f \sim 110 \mathrm{~Hz}$ で共鳴状態になることがわかった．この周 波数 $110 \mathrm{~Hz}$ に $f$ 固定した. $f=110 \mathrm{~Hz}$ を用いると

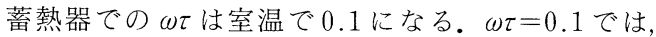
圧力変動による温度変動は流路断面にわたってほとん どなく(15)，流体と固体壁の温度はほぼ等しい。

\section{4. 音場 の測 定}

1 章でも述べたように，熱音響エンジンや熱駆動熱 音響冷凍機の研究によって,ループ状の共鳴管内には 進行波音波の励起が可能であることが報告されてい る.しかし，ループ状の管内に定在波音波が励起する
ことも確認されている(16)(17). そこで, 装置内の音波 を調べるために，管壁に取付けた圧力センサを用いて 装置内の圧力変動 $P$ を測定した。さらに測定した 2 点の圧力 $\left[P\left(x_{1}\right), P\left(x_{2}\right)\right]$ から流速 $U\left(x_{1} / 2+x_{2} / 2\right)$ を 算出した. 圧力測定から流速 $U$ を求める方法 (以後, 2 センサ法と呼ぶ)の詳細は文献(18)を参照されたい.

\section{$4 \cdot 1$ 圧力振幅 $p$, 流速振幅 $u$, 位相差 $\Phi$ の分布} 測定した圧力変動の振幅 $p$ および, 2 センサ法により 算出した流速振幅 $u$ と圧力と流速の間の位相差 $\Phi$ の 分布を図 4(a)，（b）に示す。また，付録に示した管 内を音波が伝ぱするようすを表現する式と実験デー夕 を用いて求めた ととU，および $\Phi$ の分布を線で示し た。 2 センサ法に用いられる式 [文献(18)の式(20)] から見積もった流速振幅 $u$ と位相差 $\Phi$ の誤差はそれ ぞれ図 4 中に示したシンボルの大きさ以下であった。 そのため, 図 4(a), (b)には, エラーバーが記されて いない.

図 4( a ) からわかるように, 圧力振幅は $x=0.12 \mathrm{~m}$ で $940 \mathrm{~Pa}$ となり, 蓄熱器までは $(x<0.67 \mathrm{~m}) x$ の増 加とともに増加する。一方, 流速振幅は $x=0.12 \mathrm{~m}$
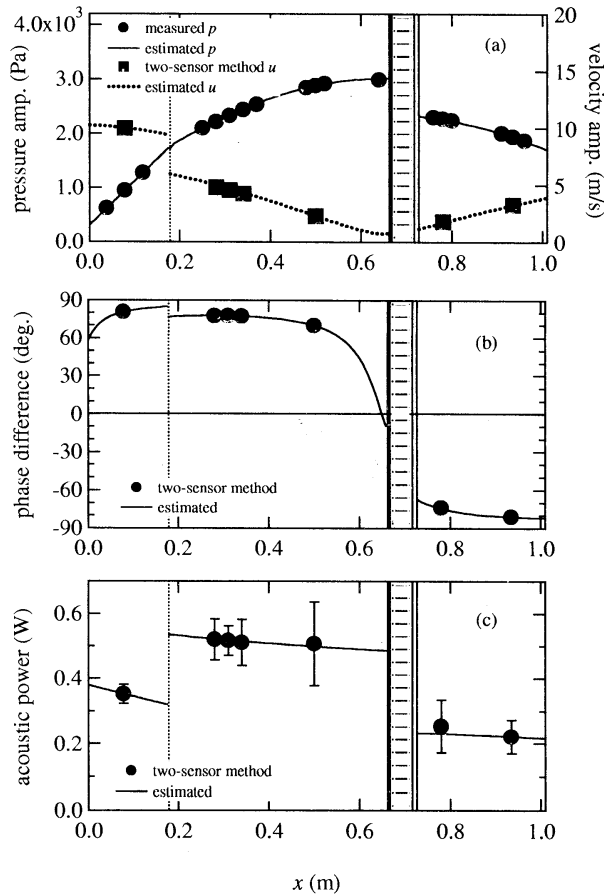

Fig. 4 Acoustic field formed in the refrigerator. (a) The distributions of pressure amplitude $p$ and velocity amplitude $u$. (b) The distribution of the phase difference $\Phi$ between pressure $P$ and velocity $U$. (c) The distribution of acoustic power flow $W$ 
で $10 \mathrm{~m} / \mathrm{s}$ となり，流路が分岐する $x=0.18 \mathrm{~m}$ で不連 続的に小さくなり, 蓄熱器までは $(x<0.67 \mathrm{~m}) x$ の増 加とともに減少している.これら分布から判断して, 装置内では, $1 / 4$ 波長共鳴が起こっているといえる.

図 4(b)に示した圧力と流速の間の位相差 $\Phi$ の分 布に注目する. 枝管内 $0 \mathrm{~m}<x<0.18 \mathrm{~m}$ やループ管内 の一部の領域 $0.18 \mathrm{~m}<x<0.4 \mathrm{~m}$ では $\Phi$ は $90^{\circ}$ に近 い值になっている.しかし，Фは蓄熱器付近で零にな り, 蓄熱器の一端では $5^{\circ}$ 程度, もう一端では $50^{\circ}$ 程度 になっている.したがって, 蓄熱器内では進行波成分 が支配的である。

蓄熱器内では $\omega \tau=0.1$ であり, 上述のように実験に より進行波成分が支配的であることがわかった。これ は, 蓄熱器内において, 等温可逆的な熱交換を利用し た進行波成分によるヒートポンフプ効果が生じているこ とを示している. 蓄熱器内において $-\pi / 2<\Phi<\pi / 2$ なので, 進行波成分による熱流の向きは， $x$ 軸の負の 方向である.つまり, 熱交換器 $\mathrm{B}$ から熱交換器 $\mathrm{A} の$ 方向になる.そこで, 熱交換器 $\mathrm{A}$ を温度 $T_{H}=26^{\circ} \mathrm{C}$ に 保ち, 熱交換器 $\mathrm{B}$ の温度 $T_{C}$ を $\mathrm{K}$ 形熱電対で測定し た.その結果, $T_{C}$ は室温より約 $8^{\circ} \mathrm{C}$ 低い $18.5^{\circ} \mathrm{C}$ にな つた.

$4 \cdot 2$ 音響パワーの分布 共鳴管冷凍機ではスピ 一力から音響パワー $W$ が入力され, 音響パワー $W$ が蓄熱器内で熱流にエネルギー変換される. 装置に投 入された音響パワーや蓄熱器に投入された音響パワー を明らかにするために, 装置内の音響パワーの分布を 調べた。

音響パワー $W$ は流路断面積 $A$, 圧力 $P$, 流速 $U$ を 用いて

$$
W=A f \int_{0}^{T} P U d t
$$

と定義されている.ここで $T$ は周期 $(=1 / f)$ である. 定義からわかるように, $W$ の大きさは図 $2(\mathrm{~d})$ に示し た進行波成分が $P-\xi$ 平面に描くだ円の面積に周波数 $f$ と断面積 $A$ を書けた値になる。 $W$ の符号はその方 向を表す. 正の值のとき, $W$ は $x$ 軸の正の方向へ向 かい, 負の值のとき, $x$ 軸の負の方向へ向かう. 式 (1)拈よび式 (2)を式 (5)に代入することで

$$
W=\frac{A}{2} p u \cos \Phi
$$

が得られる。

図 4(a)，（b)に示した $p, u, \Phi$ を用いて求めた $W$ の分布を図 4 ( c ) に示す. 図 4(c) 加わかるように $W$ はどの位置 $x$ でもつねに正の值をとっている。こ れは, $W$ の方向が $x$ 軸の正の方向であることを示し
ている。したがって，Wは枝管内をスピーカから枝 管とループ管との付け根の方向に進み, ループ管内を 時計回りに進む。

図 4(c) から， $x=0 \mathrm{~m}$ での $W$ が $0.38 \mathrm{~W}$ であるこ とがわかる.この值がスピーカから冷凍機に投入され た音響パワーの大きさである。 $W$ は $x$ の正の方向へ 進み, $x=0.12 \mathrm{~m}$ では, その大きさが $0.35 \mathrm{~W}$ に減少 している. 滅少した原因は, 粘性と熱伝導により, 散 逸が生じたためである．Wはさらに $x$ を正の方向へ 進み分岐点である $x=0.18 \mathrm{~m}$ に達する.この点で, 不連続的に $W$ は大きくなっている. その結果, スピ 一カから入力された音響パワー $W(x=0)$ を上回る音 響パワーが蓄熱器へ入力されている. 蓄熱器ではエネ ルギー変換と狭い流路内で起こる散逸の結果, 音響パ ワーは他の位置に比べて大きく減少する. 蓄熱器低温 端 $(x=0.73 \mathrm{~m})$ から出力された音響パワーは, $x=$ $1.01 \mathrm{~m}(=0.18 \mathrm{~m})$ でスピーカから入力された音響パ ワーと合流し, 再び蓄熱器に入力される.この合流が 上記した $x=0.18 \mathrm{~m}$ で $W$ が不連続的に大きくなっ た原因である.

上述のように，製作した共鳴管冷凍機では，ループ 状の経路が存在することで, 蓄熱器から出力された音 響パワーは再び蓄熱器に入力されていた. 図 1 からも わかるように, 従来の共鳴管冷凍機では音響パワーの 再利用は実現されない. 進行波成分を用いた冷凍機で は蓄熱器低温端から出力された音響パワーが再び蓄熱 器に入力されるとき, その冷凍機の COP の上限值は $\mathrm{COP}_{\text {Carnot }}=T_{C} /\left(T_{H}-T_{C}\right)$ に等しくなり, されない場 合の COPの上限值 $T_{C} / T_{H}$ を上回る(9)(19). したがっ て, ループ状の共鳴管を利用することは, 進行波成分 によるヒートポンプ効果を実現させるだけでなく, COP の改善にも寄与する可能性がある.

\section{5. 冷凍機の性能}

$5 \cdot 1$ 低温端の温度の音響パワー依存性計測可 能な最も小さな $x$ での音響パワー $W(x=0.12) を$ $W_{\text {in }}$ と定義し， $W_{\text {in }}$ を変えながら $T_{C}$ を測定した。測 定した $T_{C}$ を $T_{C, a}$ として, 図 5 に白抜きの四角で示 した。 なお，黒四角で示した $T_{C, b}$ については 6 章で 述べる. 図 5 からわかるように, $W_{\text {in }}$ を零から徐々に 増加させると, $T_{c, a}$ は低下した. $W_{\mathrm{in}}=1.8 \mathrm{~W}$ のとき,

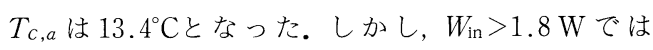
$W_{\mathrm{in}}$ を増加させても, ほとんど $T_{c, a}$ は変化しなかっ た.

蓄熱器に流れ込む $W$ を増加させても, 蓄熱器の低 温端の温度が減少しない現象は熱駆動熱音響冷凍機で 


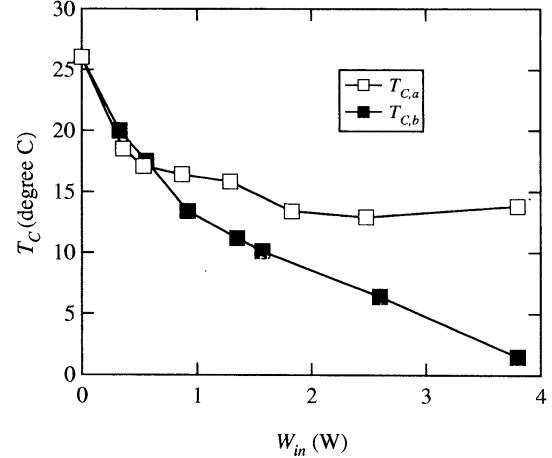

Fig. 5 Measured $T_{C}$ as a function of $W_{i n}$

も確認されている(9)(10).この原因としてループ状の流 路を周回する質量流 $M_{2,0}$ の影響が指摘されてい $3^{(9)(10)}$. 質量流 $M_{2,0}$ は

$$
M_{2,0}=A f \int_{0}^{T} \rho U d t+A \rho_{m} U_{2,0} .
$$

と書ける(9). $\rho$ は密度の平均值 $\rho_{m}$ からのずれを表す. また $U_{2,0}$ は, 流速が周期的に変動するために誘起され る二次的な流速で, 時間に依存しない. 質量流 $M_{2,0}$ が有限であると, 熱負荷 $Q_{\text {load }}=M_{2,0} C_{p}\left(T_{H}-T_{C}\right)$ が低 温熱交換器に加わるので, 冷凍機の性能は低下す $ろ^{(9)}$.

$5 \cdot 2$ 質量流の抑制 冷凍機の性能を向上させる ために，質量流 $M_{2,0}$ の抑制を試みた。質量流はゴム 膜によって抑制できると報告されている(9). そこで, 著者らはゴム膜(風船)を装置内に設置した。ゴム膜の 変位をできるだけ小さくするために，ゴム膜の設置位 置は流速の節付近である $x=0.65 \mathrm{~m}$ とした.

式 ( 7 )の右辺の第 1 項は $W$ と同じ符号をもち, そ の大きさは $W$ の大きさに比例する。なぜなら

$$
\int_{0}^{T} \rho U d t \propto \frac{\rho_{m}}{P_{m}} \int_{0}^{T} P U d t
$$

の関係が満たされる(3) からである。したがって, 式 ( 7 )の右辺の第 1 項の符号と大きさは $W$ に依存す る. 一方, 第 2 項の符号と大きさは音波によって誘起 される時間に依存しない二次的な圧力 $P_{2,0}$ のこう配に 依存する。なぜなら， $P_{2,0}$ のこう配と $U_{2,0}$ は

$$
U_{2,0} \propto-\frac{d P_{2,0}}{d x}
$$

の関係で結ばれる(9) からである。そこで， $W_{\mathrm{in}}$ を変え ながら, 蓄熱器を挟んだ位置 $x=0.66 \mathrm{~m}$ と $x=0.76$ $\mathrm{m}$ での $P_{2,0}$ の差を測定 ${ }^{(20)}$ した.

蓄熱器を挟んだ位置 $x=0.66 \mathrm{~m}$ と $x=0.76 \mathrm{~m}$ での $P_{2,0}$ の差

$$
\Delta P_{2,0}=P_{2,0}(x=0.76)-P_{2,0}(x=0.66)
$$

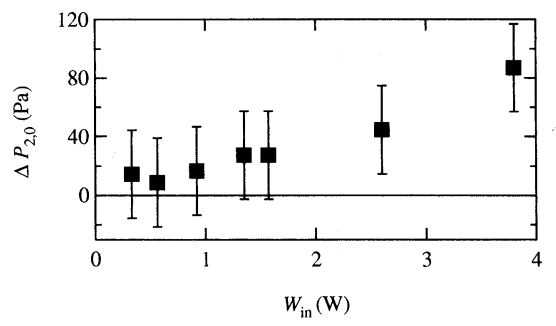

Fig. 6 Measured $\Delta P_{2,0}$ plotted as a function of $W_{\text {in }}$

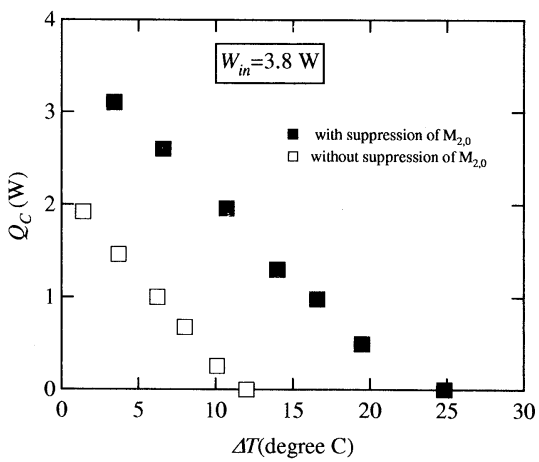

Fig. 7 Cooling power of the refrigerator

を $W_{\text {in }}$ の関係として図 6 に示した. 図 6 から $\Delta P_{2,0}$ の 符合は正であることがわかる。これは, $d P_{2,0} / d x>0$ であることを意味している．したがって， $U_{2,0}$ は負で あり, 音響パワー $W$ とは逆に蓄熱器の中を低温端か ら高温端に向かっている。これは式 ( 7 )の右辺第 1 項 と第 2 項が異なる符合をもつことを意味している。ま た，図 6 から， $W_{\text {in }}$ を大きくすると $\Delta P_{2,0}$ の大きさが大 きくなることがわかる，これは， $W_{\text {in }}$ の増加とともに $U_{2,0}$ の大きさが大きくなることを意味している. した がって, 式（７）の右辺第 1 項の大きさが大きくなると, 第 2 項の大きさも大きくなっている．これら実験結果 から判断して,ゴム膜によって質量流 $M_{2,0}$ は抑制さ れている。

ゴム膜を設置した状態で, $W_{\text {in }}$ を変えながら蓄熱器 低温端の温度 $T_{C}$ を測定した。測定した温度を $T_{C, b}$ とした. $T_{C, b}$ と $W_{\text {in }}$ の関係を図 5 に黒四角で示す. 図 5 から $W_{\text {in }}$ をきくすると $T_{C, b}$ は単調に減少する ことがわかる.また， $T_{C, b}$ と $T_{C, a}$ を比べると明らか なように，ゴム膜を設置することで，冷凍機の最低到 達温度が低下した。 $W_{\text {in }}$ が $3.8 \mathrm{~W}$ のとき, $T_{C, b}$ は $T_{H}$ から約 $25^{\circ} \mathrm{C}$ 低い $1.7^{\circ} \mathrm{C}$ にった。

低温熱交換器にヒー夕線を巻きつけ，熱負荷を加え 冷凍出力 $Q_{C}$ を測定した. $Q_{C}$ は直流安定化電源 (KENWOOD, PW 18-3 AD, 電力測定誤差 $\pm 2 \%$ 以 
下)を用いてヒータ線に加えた電力とした， $W_{\text {in を本 }}$ 実験における最大值 $3.8 \mathrm{~W}$ に固定した. 冷凍出力 $Q_{c}$ と $\Delta T=T_{H}-T_{C}$ の関係を図 7 に示した.ここでゴム 膜を設置した状態で測定した $Q_{C}$ を黒塗りの四角で, ゴム膜を設置しない状態で測定した $Q_{c}$ を白抜きの四 角で示した. どの $\Delta T$ で比べても，ゴム膜を設置した ときの冷凍出力 $Q_{c}$ は設置しないときの冷凍出力を上 回った. $\Delta T=10^{\circ} \mathrm{C}$ のき，ゴム膜を設置しないとき

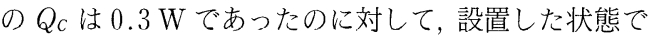
の $Q_{c}$ は $2.0 \mathrm{~W}$ であった.この冷凍機の成績係数を $\mathrm{COP}=Q_{c} / W_{\mathrm{in}}$ と定義すると, $\Delta T=10^{\circ} \mathrm{C}$ 時のゴム膜 を設置しない状態での COPは 0.08 で, 設置した状態 での COP は 0.53 となる。この結果からゴム膜の設 置によって質量流 $M_{2,0}$ を制することは, ループ管を 用いた共鳴管冷凍機の COP を向上させるといえる.

\section{6. 結 論}

ループ状の共鳴管を用いて共鳴管冷凍機を製作し た. 圧力変動を調べることで, この冷凍機は進行波成 分を用いてヒートポンプ効果を得ていることを明らか にした.さらに,ゴム膜を挿入することで, 質量流を 抑制し, 製作した冷凍機の性能を向上させた。冷凍機 の COP は $\Delta T=T_{H}-T_{C}=10^{\circ} \mathrm{C}$ とき, 0.54 であっ た.

今回の装置では低温熱交換器や蓄熱器を外界と断熱 していない. したがって, 断熱することで, 冷凍出力 $Q_{C}$ の増大と, COP の改善が期待できる.また, 作動 流体を高圧化しエネルギー密度を上げることで, COP の改善が期待できる。なぜなら，エネルギー密度を上 げることで，固体壁を伝わる熱伝導など温度差が原因 になって生じるロスに比べて, 音波によるヒートポン プ効果によって運ばれる熱量が相対的に増え, ロスが COPに与える影響が小さくなると期待できるからで ある。

本論文の作成にあたり, 愛知教育大学教授 矢崎太 一氏に貴重なご意見をいただいた。氏にお礼申し上げ る. 本研究は日本学術振興会特別研究員制度および科 学研究費(科研費番号 10613) の援助を得て実施され た.また，本論文で述べた共鳴管冷凍機は東京大学生 産技術研究所試作工場の協力を得て製作された.

\section{[付録]}

線形化した非圧縮性流体の Navier-Stokes 方程式 を，長波長近似と壁での流速が零とする境界条件を用 いて，書き直すと，

$$
\rho_{m} \frac{\partial U(x, t)}{\partial t}=-\frac{\partial P(x, t)}{\partial x}\left(1-\chi_{\nu}\right)
$$

となる(4).ここで $x$ は音波の伝ぱ方向にとつた軸であ る. $\chi_{\nu}$ は流速の管の半径方向 $r$ の分布関数 $F(r)$ を 断面平均することで得られ， $\omega \tau_{\nu}$ の関数である. $\omega \tau_{\nu}$ は動粘性係数 $と$ 角振動数 $\omega$, 流路径 $r_{0}$ を用いて $\omega \tau_{\nu}=\omega r_{0}^{2} /(2 \nu)$ と書け, 論文中で用いた $\omega \tau$ とは, プ ラントル数 $\sigma$ を用いて $\omega \tau_{\nu}=\omega \tau / \sigma$ の関係で結ばれて いる. $\omega \tau_{\nu} \gg 1$ の条件のとき

$$
\chi_{\nu}=(1-i) / \sqrt{\omega \tau_{\nu}}
$$

と書ける(18). 条件 $\omega \tau_{\nu} \gg 1$ は粘性の影響が小さい太い 管内で成り立つ。

圧力変動 $P$ と流速変動 $U$ をそれぞれ複素数表示す ると,

$$
\begin{aligned}
& P(x, t)=p(x) \exp [i \omega t] \cdots \cdots \cdots \cdots \cdots . . . \\
& U(x, t)=u(x) \exp [i\{\omega t+\Phi(x)\}] .
\end{aligned}
$$

と書ける。式(14)を式(11)に代入すると

$$
U(x, t)=\frac{i}{\omega \rho_{m}} \frac{\partial P(x, t)}{\partial x}\left(1-\chi_{\nu}\right)
$$

が得られる。

圧力変動を右向きの進行波と左向きの進行波の重ね 合わせで表現すると

$$
P(x, t)=C_{+} e^{i(\omega t-k x)}+C_{-} e^{i(\omega t+k x)}
$$

と書ける(18).ここで， $C_{+}$と $C_{-}$愎複素数の定数であ り, $k$ は複素波数である。 $k$ は $\omega \tau_{\nu} \gg 1$ のとき

$$
k=\frac{\omega}{a}\left\{1+\frac{1-i}{2 \sqrt{\omega \tau_{\nu}}}+\frac{(1-i)(\gamma-1)}{2 \sqrt{\omega \tau}}\right\}
$$

となる(18).ここで $a$ は断熱音速であり $\gamma$ は比熱比で ある．式(15)，(16)を用いると，ある位置 $x_{0}$ での圧力 変動 $P_{0}$ と流速変動 $U_{0}$ は

$$
\begin{aligned}
& P_{0}=C_{+} e^{i\left(\omega t-k x_{0}\right)}+C_{-} e^{i\left(\omega t+k x_{0}\right)} \\
& U_{0}=\frac{k\left(1-\chi_{\nu}\right)}{\omega \rho_{m}}\left(C_{+} e^{i\left(\omega t-k x_{0}\right)}\right. \\
& \left.-C_{-} e^{i\left(\omega t+k x_{0}\right)}\right)
\end{aligned}
$$

となる.この二つの式から

$$
\begin{aligned}
& C_{+}=\frac{1}{2}\left\{P_{0}+\frac{\omega \rho_{m} U_{0}}{k\left(1-\chi_{\nu}\right)}\right\} e^{-i\left(\omega t-k x_{0}\right)} \\
& C_{-}=\frac{1}{2}\left\{P_{0}-\frac{\omega \rho_{m} U_{0}}{k\left(1-\chi_{\nu}\right)}\right\} e^{-i\left(\omega t+k x_{0}\right)}
\end{aligned}
$$

が得られる。この $C_{+}, C_{-}$を式(15)，(16)に代入する ことで

$$
\begin{aligned}
& P(x, t)=\frac{1}{2}\left\{P_{0}+\frac{\omega \rho_{m} U_{0}}{k\left(1-\chi_{v}\right)}\right\} e^{-i k\left(x-x_{0}\right)} \\
& \quad+\frac{1}{2}\left\{P_{0}-\frac{\omega \rho_{m} U_{0}}{k\left(1-\chi_{\nu}\right)}\right\} e^{i k\left(x-x_{0}\right)} \quad \cdots \cdots \cdots \cdots(23) \\
& U(x, t)=\frac{k\left(1-\chi_{\nu}\right)}{2 \omega \rho_{m}}\left[\left\{P_{0}+\frac{\omega \rho_{m} U_{0}}{k\left(1-\chi_{\nu}\right)}\right\} e^{-i k\left(x-x_{0}\right)}\right. \\
& \left.\quad-\left\{P_{0}-\frac{\omega \rho_{m} U_{0}}{k\left(1-\chi_{v}\right)}\right\} e^{i k\left(x-x_{0}\right)}\right] \cdots \cdots \cdots \cdots \cdots(24)
\end{aligned}
$$


が得られる.これら式から, ある位置 $x_{0}$ における $P_{0}$ および $U_{0}$ が得られると, $P$ と $U$ の振幅の位相は $x$ の関数として得られる.

図 4 に示した線を引くために，まず装置を三つの部 分 $0 \mathrm{~m}<x<0.18 \mathrm{~m}, 0.18 \mathrm{~m}<x<0.65 \mathrm{~m}, 0.73 \mathrm{~m}<$ $x<1.01 \mathrm{~m}$ に分けた. 次に, $x=0.08,0.28,0.78 \mathrm{~m}$ で 実験的に得られた $P, U$ を $P_{0}, U_{0}$ として, それぞれの 領域で $P(x), U(x)$ を得る. 得られた $P(x), U(x)$ を 用いて, 図 4 に示した線を描いた。

\section{文献}

(1) Merkli, P. and Thomann, H., Thermoacoustic effects in a resonant tube, Journal of Fluid Mechanics, Vol. 70 (1975), pp. 161-177.

(2) Wheatley, J. and Cox, A., Natural Engines, Physics Today, Vol. 38 (1985), pp. 50-58.

(3) Swift, G. W., Thermoacoustic Engines and Refrigerators, Physics Today, Vol.48 (1995), pp. 22-28; the Journal of the Acoustical Society of America, Vol. 84 (1988), pp. 1145-1180; Thermoacoustics, published by Acoustical Society of America.

(4) Tominage, A., Thermodynamic Aspects of Thermoacoustic Theory, Cryogenics, Vol. 35 (1995), pp. 427-440.

( 5 ) Ceperley, P. H., A Pistonless Stirling Engine-Traveling Wave Heat Engine, The Journal of the Acoustical Society of America, Vol. 66 (1979), pp. 1508-1513.

(6) Yazaki, T. et al., Traveling Wave Thermoacoustic Engine in a Looped Tube, Physical Review Letters, Vol. 81 (1998), pp. 3128-3131.

(7) Backhaus, S. and Swift, G. W., A Thermoacoustic Stirling Heat Engine, Nature (London), Vol. 399 (1999), pp. 335-338; A Thermoacoustic-Stirling Heat Engine: Detailed Study, The Journal of the Acoustical Society of America, Vol. 107 (2000), pp. 3148-3166.
(8) Ueda, Y. et al., Acoustic Field in a Thermoacoustic Stirling Engine Having a Looped Tube and Resonator, Applied Physics Letters, Vol. 81 (2002), pp. 5252-5254.

(9) Swift, G. W. et al., Acoustic Recovery of Lost Power in Pulse Tube Refrigerators, The Journal of the Acoustical Society of America, Vol. 105 (1999), pp. 711-724.

(10) Yazaki, T. et al., A Pistonless Stirling Cooler, Applied Physics Letters, Vol. 80 (2002), pp. 157-159.

(11) Ueda, Y. et al., Experimental Studies of a Thermoacoustic Stirling Prime Mover and its Application to a Cooler, The Journal of the Acoustical Society of America, Vol. 115 (2004), pp. 1134-1141.

(12) Miwa, M. et al., Measurement of Acoustic Output Power in a Traveling Wave Engine, submitted to Ultrasonics.

(13) Biwa, T. et al., Experimental Demonstration of Thermoacoustic Energy Conversion in a Resonator, Physical Review E, (2004), Art. No. 066304.

(14) Inoue, T., Cooling by Sound Wave, Refrigeration, Vol. 69 (1994), pp. 76-83.

(15) Tashiro, Y. et al., Calibration of a Thermocouple for Measurement of Oscillating Temperature, Review of Scientific Instruments, Vol. 76 (2005), Art. No. 124901.

(16) Biwa, T. et al., Work Flow Measurements in a Thermoacoustic Engine, Cryogenics, Vol. 41 (2001), pp. 305 310.

(17) Biwa, T. et al., Thermodynamical Mode Selection Rule Obserbed in Thermoacoustic Oscillations, Europhysics Letters, Vol. 60 (2002), pp. 363-368.

(18) Fusco, A. et al., 2-Sensor Power Measurements in Lossy Ducts, The Journal of the Acoustical Society of America, Vol. 91 (1992), pp. 2229-2235.

(19) Ueda, Y. and Biwa, T., Efficiencies of a Pulse-Tube Refrigerator and a Heat-Driven Thermoacoustic Cooler, Teionkogaku, Vol. 41 (2005), pp. 73-80 (in Japanese).

(20) Smith, B. L. and Swift, G. W., Measuring Secondorder Time Average Pressure, The Journal of the Acoustical Society of America, Vol.110 (2001), pp. 717-723. 